\title{
Kemampuan Penalaran Proporsional Siswa dalam Menyelesaikan
} Masalah Pra-Multiplikatif

\author{
Fuat $^{1 *)}$, \& Mujiati Puspita Wulan ${ }^{2}$ \\ ${ }^{1,2}$ Universitas PGRI Wiranegara, Pasuruan, Indonesia
}

\section{INFO ARTICLES}

Article History:

Received: 17-02-2021

Revised: 14-06-2021

Approved: 18-06-2021

Publish Online: 30-06-2021

\section{Key Words:}

Proportional Reasoning; PreMultiplicative Problems;

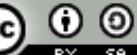
under a Creative Commons AttributionShareAlike 4.0 International License.

\begin{abstract}
One of the students' reasoning ability need to be developed is proportional reasoning abilities as the basic reasoning of the five types of reasoning that have been expressed by Piaget. This types of research is a qualitative descriptive research that aims to categorize first middle class students' proportional reasoning abilities in solving pre-multiplicative problems. This reseach used purposive sampling technique, namely the selection of subjects with certain considerations to get subjects who have different categories of proportional reasoning. The instrument was a written test of a three point description and guiding interview. Then, the analysis activity used Miles and Huberman models of data reduction, data display, and conclusion drawing/verification. Based on the results of the research, it can be concluded that the development of proportional reasoning abilities mastered by students is different, namely subject 1 reaches category 3, subject 2 reaches category 1 and subject 3 reaches category 0.
\end{abstract}

\begin{abstract}
Abstrak: Salah satu kemampuan bernalar siswa yang perlu dikembangkan adalah kemampuan penalaran proporsional sebagai penalaran dasar dari kelima jenis penalaran yang telah diungkapkan oleh Piaget. Jenis penelitian ini merupakan penelitian deskriptif kualitatif yang bertujuan untuk mengkategorikan kemampuan penalaran proporsional siswa kelas menengah pertama dalam menyelesaikan masalah pra-multiplikatif. Penelitian ini menggunakan teknik Purposive Sampling yaitu pemilihan subjek dengan pertimbangan tertentu untuk mendapatkan subjek yang memiliki kategori penalaran proporsional berbeda. Instrumen yang digunakan adalah tes tertulis berupa uraian berjumlah tiga soal dan pedoman wawancara. Kemudian dilanjutkan dengan kegiatan analisis data menggunakan model Miles dan Huberman yang terdiri dari reduksi data, penyajian data, dan penarikan kesimpulan. Berdasarkan hasil penelitian, dapat disimpulkan bahwa perkembangan kemampuan penalaran proporsional yang dikuasai siswa berbeda-beda yaitu subjek 1 mencapai kategori 3 , subjek 2 mencapai kategori 1 dan subjek 3 mencapai kategori 0 .
\end{abstract}

Correspondence Address: Jl. Ki Hajar Dewantara No.27-29, Pasuruan, 67118, Indonesia; e-mail: boozfuat@gmail.com

How to Cite (APA $6^{\text {th }}$ Style): Fuat, F., \& Wulan, M.P. (2021). Kemampuan Penalaran Proporsional Siswa dalam Menyelesaikan Masalah Pra-Multiplikatif. JKPM (Jurnal Kajian Pendidikan Matematika), 6(2): 179-190

Copyright: 2021 Fuat Fuat, Mujiati Puspita Wulan

Competing Interests Disclosures: The authors declare that they have no significant competing financial, professional or personal interests that might have influenced the performance or presentation of the work described in this manuscript. 


\section{PENDAHULUAN}

Pembelajaran matematika saat ini terfokus pada hal yang prosedural. Seringkali guru mengajarkan konsep dasar matematika dengan menghafal rumus tanpa melibatkan siswa untuk menemukan konsep yang harus dikuasai. Sehingga siswa cenderung pasif dengan hanya berlatih soal rutin dan pengerjaan didasarkan pada contoh soal yang telah diberikan oleh guru. Dalam proses pembelajaran, siswa diharapkan mampu menerapkan kompetensi suatu mata pelajaran yang telah disajikan dan dipelajari secara konstruktivis (Uyun, \& Fuat, 2020). Ketika diberikan soal tidak rutin seperti soal penerapan kehidupan sehari-hari, banyak dari siswa kesulitan untuk bernalar dalam menghubungkan prakonsepsi dan konsepsi yang digunakan untuk menentukan penyelesaian dari suatu masalah. Prakonsepsi dapat diartikan sebagai konsep awal yang dimiliki seseorang dan konsep tersebut diperoleh sebelum mereka menerima pelajaran formal di sekolah, sedangkan konsepsi dapat diartikan sebagai pemikiran setiap orang mengenai suatu konsep yang diperoleh dari pengalamannya (Fuat, dkk., 2020). Oleh karena itu, tidak adanya pemahaman konsep dasar matematika yang baik akan berdampak pada kemampuan bernalar siswa.

Studi-studi tentang penalaran secara historis berhubungan dengan studi-studi tentang logika. Penalaran diartikan sebagai upaya logis untuk menghubungkan beberapa pernyataan agar mendapat suatu kesimpulan (Fuat, dkk., 2020). Kemampuan bernalar siswa memiliki peranan penting dalam mempelajari bidang matematika. Dengan kemampuan bernalarnya, manusia dapat berpikir untuk menarik kesimpulan atau menyusun pernyataan baru dari beberapa premis yang sudah diketahui atau dianggap benar, dan membuktikan suatu apakah pernyataan tersebut benar atau tidak (Fuat, 2020). Dari beberapa pendapat tersebut, proses penalaran dapat diartikan sebagai seseorang yang bergerak menuju pada proses mendapatkan pengetahuan baru berdasarkan pengetahuan yang telah dimiliki sebelumnya.

Salah satu kemampuan bernalar siswa yang perlu dikembangkan adalah kemampuan penalaran proporsional sebagai penalaran dasar dari kelima jenis penalaran yang telah diungkapkan oleh Piaget. Piaget mengungkapkan dalam teori perkembangan kognitif pada tingkat berpikir operasional formal dengan mengklasifikasikan menjadi 5 jenis penalaran, yaitu penalaran proporsional, pengontrolan variabel, penalaran probabilistik, penalaran korelasional, dan penalaran kombinatorial. Menurut pendapat Lest, Post, \& Behr dalam (Walle, 2007) yang menyatakan bahwa Penalaran Proporsional (Proporsional Reasoning) telah dirujuk sebagai pencapaian utama dari kurikulum sekolah dasar dan fondasi dari aljabar dan sesudahnya.

Menurut Piaget dalam (Irawati, 2015) penalaran proporsional dapat diartikan sebagai suatu struktur kualitatif yang memungkinkan pemahaman sistem-sistem fisik kompleks yang mengandung banyak faktor. Piaget mengartikan pemahaman sistem fisik kompleks sebagai pemahaman yang berkaitan dengan proporsi atau rasio. Berbeda dengan pendapat Walle (2007) yang mengartikan bahwa Penalaran Proporsional mewakili kemampuan untuk mulai memahami hubungan perkalian di mana sebagian besar konsep aritmatika biasanya berdasarkan penjumlahan. Dari kedua pendapat tersebut, penulis menyimpulkan bahwa penalaran proporsional adalah kemampuan siswa memahami perubahan kuantitas terhadap kuantitas lain pada situasi proporsi atau rasio dengan melibatkan hubungan multiplikatif.

Menurut Lamon dalam (Ojose, 2015) mencatat ada beberapa karakteristik pemikir proporsional, yaitu memahami kovariasi, mengenali hubungan proporsional dan non proporsional, mengembangkan banyak strategi untuk menyelesaikan proporsi atau membandingkan rasio, dan memahami rasio. Dari beberapa karakteristik tersebut, tentunya setiap siswa memiliki perkembangan penalaran proporsional yang berbeda-beda. Untuk lebih mengembangkan kemampuan penalaran proporsional siswa, guru perlu memberikan latihan soal kepada siswa berupa permasalahan proporsional yang erat kaitannya dengan situasi proporsi dan rasio.

Dalam penelitian ini, digunakan tiga tipe masalah proporsional yang akan diberikan kepada siswa, yaitu (a) Membandingkan dan Memprediksi Masalah secara Kualitatif (Qualitative 
Prediction and Comparison Problems), contoh dari tipe masalah ini adalah jika diketahui dua rasio pada soal cerita yang diberikan, siswa diminta untuk menentukan hubungan dari kedua rasio tersebut apakah menggunakan hubungan perbandingan senilai atau perbandingan tidak senilai; (b) Membandingkan Rasio (Numerical Comparison), contoh dari tipe masalah ini adalah jika diketahui dua rasio, siswa diminta membandingkan kedua rasio tersebut seperti halnya mengidentifikasi rasio ekuivalen; (c) Mencari nilai yang belum diketahui (missing value problem), contoh dari tipe masalah ini adalah jika diketahui proporsi $\frac{a}{b}=\frac{c}{d}$ dengan ketiga nilai yang diketahui dan satu nilai belum diketahui. Pada tipe masalah tersebut, siswa mulai mempertimbangkan untuk menggunakan kemampuan multiplikatif atau aditif dalam penyelesaian masalah.

Dalam penelitian ini, digunakan empat kategori penalaran proporsional yang didasarkan pada banyak kemampuan siswa dalam menyelesaikan tipe masalah penalaran proporsional, yaitu: 1) Kategori 0. Pada kategori ini, siswa tidak menguasai kemampuan untuk menyelesaikan tipe masalah penalaran proporsional. Hal tersebut dapat terlihat pada ketidakmampuan siswa dalam menjawab dengan benar dari ketiga tipe masalah yang diberikan peneliti; 2) Kategori 1. Pada kategori ini, siswa menguasai satu kemampuan untuk menyelesaikan tipe masalah penalaran proporsional. Hal tersebut berdasarkan pada jawaban benar satu tipe masalah dari ketiga tipe masalah yang diberikan peneliti. 3) Kategori 2. Pada kategori ini, siswa menguasai dua kemampuan untuk menyelesaikan tipe masalah penalaran proporsional. Hal tersebut berdasarkan pada jawaban benar dua tipe masalah dari ketiga tipe masalah yang diberikan peneliti. 4) Kategori 3. Pada kategori ini, siswa menguasai tiga kemampuan menyelesaikan tipe masalah penalaran proporsional. Hal tersebut berdasarkan pada jawaban benar ketiga tipe soal yang diberikan peneliti.

Berdasarkan uraian di atas, muncul ketertarikan untuk menganalisis kemampuan penalaran proporsional siswa SMP khususnya pada pokok bahasan perbandingan. Oleh karena itu, dalam penelitian ini penulis memilih judul "Kemampuan Penalaran Proporsional Siswa Kelas Menengah dalam Menyelesaikan Masalah Pra-Multiplikatif".

\section{METODE}

Jenis penelitian ini merupakan penelitian deskriptif kualitatif yang bertujuan untuk mengkategorikan kemampuan penalaran proporsional siswa kelas menengah pertama dalam menyelesaikan masalah pra-multiplikatif. Instrumen yang digunakan adalah tes tertulis berupa uraian berjumlah tiga soal dan pedoman wawancara. Kemudian dilanjutkan dengan kegiatan analisis data menggunakan model Miles dan Huberman yang terdiri dari reduksi data, penyajian data, dan penarikan kesimpulan. Penelitian ini menggunakan teknik purposive sampling yaitu pemilihan subjek dengan pertimbangan tertentu untuk mendapatkan subjek yang memiliki kategori penalaran proporsional berbeda.

Pada penelitian ini subjek peneliti diambil secara acak sebanyak 8 subjek pada jenjang sekolah menengah pertama kelas VIII dan IX dengan pertimbangan subjek peneliti telah menempuh materi tentang pecahan dan perbandingan. Selanjutnya 8 subjek tersebut dikelompokkan menurut kategori yang sama berdasarkan hasil tes penalaran proporsional pramultiplikatif yaitu MAF pada kategori 3; NR dan MD pada kategori 2; FAF, AN, AHR, SAP, dan MD berada pada kategori 1. Setelah dikategorikan, maka hanya diambil satu subjek tiap kategori untuk dianalisis lebih mendalam terkait hasil penyelesaian masalah yaitu MAF sebagai subjek 1 (S1), NR sebagai subjek 2 (S2), dan AHR sebagai subjek 3 (S3). Selain itu pertimbangan dalam pemilihan subjek terletak pada kemampuan subjek dalam berargumen untuk menjelaskan kembali hasil penyelesaian masalah yang diberikan.

Oleh karena itu, perlu dilakukan wawancara untuk mengetahui argumen subjek peneliti sehingga menjadi data pendukung penelitian ini serta mengetahui lebih jauh tentang proses 
berpikir siswa dalam menyelesaikan masalah yang diberikan. Berikut instrumen yang digunakan dalam penelitian ini.

Fitri dan Ayu berencana akan membuat jus buah dan menjualnya kepada temantemannya. Mereka membuat jus buah dengan campuran sari jus dan air dingin. Untuk membuat minuman tersebut, mereka menguji dua resep jus.

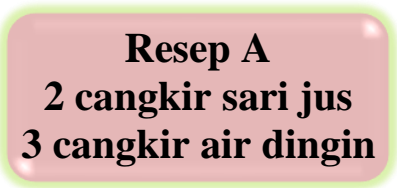

\section{Resep B \\ 4 cangkir sari jus \\ 8 cangkir air dingin}

Berdasarkan kedua resep tersebut, tentukan:

a. Dalam menentukan campuran sari jus dan air dingin pada kedua resep, konsep perbandingan senilai ataukah perbandingan berbalik nilai yang harus digunakan Fitri dan Ayu? Jelaskan alasan Anda.

b. Resep manakah yang akan membuat jus paling kental? Jelaskan jawaban Anda.

c. Jika Fitri dan Ayu ingin menggunakan resep A untuk membuat 12 cangkir sari jus, maka berapakah banyak cangkir air dingin yang dibutuhkan?

\section{HASIL}

Berdasarkan data yang diperoleh, berikut ini disajikan proses penalaran proporsional tiga subjek dengan kategori penalaran proporsional yang berbeda.

1. Penalaran proporsional pada Subjek 1 (S1)

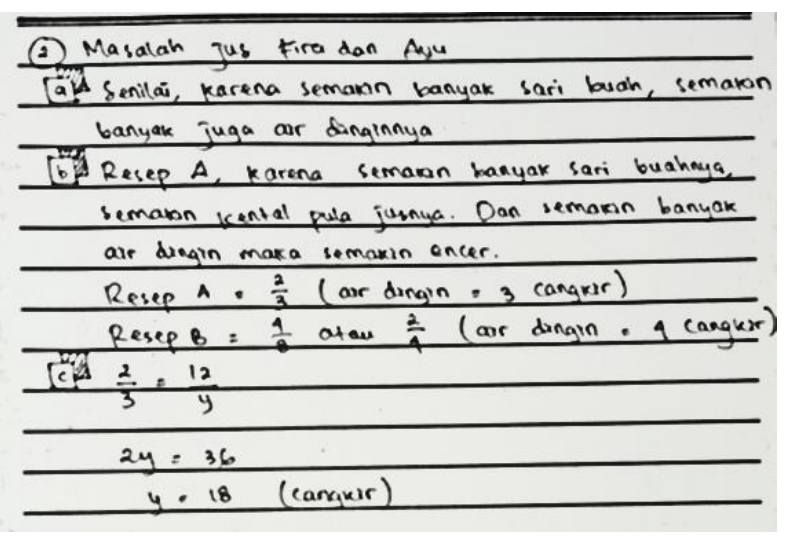

Gambar 1. Hasil Jawaban S1

Gambar 1. merupakan hasil jawaban S1 terhadap soal yang diberikan peneliti. Berdasarkan hasil jawaban S1 pada soal (a), S1 dapat menjawab bahwa pada soal (a) merupakan tipe soal perbandingan senilai dengan disertai alasan yang tepat yaitu S1 membandingkan banyak sari buah dengan banyak air dingin. Alasan S1 sesuai dengan konsep dari perbandingan senilai, karena apabila satu kuantitas semakin bertambah, maka kuantitas lainnya juga bertambah.

Pada soal (b) yaitu tipe soal membandingkan rasio, S1 dapat menjawab dengan tepat bahwa resep yang paling kental adalah resep A dibanding resep B. S1 memberikan dua alasan pada soal (b), yaitu alasan berupa deskripsi dan perhitungan. Pada alasan berupa deskripsi, S1 mengamati kedua resep sebagai satu kesatuan dan menyimpulkan secara objektif dengan menghubungkan terhadap kekentalan jus buah yang dihasilkan (lihat gambar 1). Akan tetapi, alasan berupa deskripsi tersebut didukung dengan alasan perhitungan, yang mana S1 mengubahnya menjadi bentuk pecahan, lalu menyederhanakan, membandingkan kedua 
pecahan, dan menyimpulkan bahwa antara kedua resep tersebut, resep A merupakan resep yang lebih kental. Hal tersebut didukung dengan hasil wawancara dengan S1 sebagai berikut.

Peneliti : "Lalu untuk soal (b), kamu menuliskan resep A $\frac{2}{3}$ maka air dingin yang dibutuhkan ada 3 cangkir. Maksudnya bagaimana itu? Coba jelaskan cara kamu”

S1 : "Yang paling kental ya?"

Peneliti : "Iya betul"

S1 : "Resep A, karena jika sari buahnya itu 2 cangkir air dinginnya itu cuman 3 cangkir. Sedangkan kalau resep B, jika sari buahnya 2 cangkir, air dinginnya 4 cangkir, artinya tambah encer"

Peneliti : "Jadi kamu sederhanakan dulu itu ya untuk resep B baru dibandingkan?"

S1 : "Iya"

Selanjutnya pada soal (c), S1 dapat menjawab dengan tepat banyaknya cangkir air dingin yang dicari, dengan cara membandingkan kedua rasio menggunakan konsep perbandingan senilai (lihat gambar 1). Jawaban S1 didukung dengan hasil wawancara dengan peneliti sebagai berikut.

Peneliti : "Coba kamu jelaskan bagaimana kamu menyelesaikan soal ini?"

S1 : "Perbandingan senilai, jadi 2 itu sari jus dan 3 itu air dingin sama dengan 12 itu sari jus dan yang ditanyakan y itu air dingin"

Peneliti : "Jadi kamu memisalkan dulu ya?. Lalu setelah itu?"

S1 : "Iya dimisalkan. Setelah itu dikali silang $2 y=36$, jadi y didapat dari 36 dibagi

2 hasilnya 18"

Peneliti : "Oke baik. Lalu saya misalkan kedua rasio itu menjadi $\frac{2}{12}=\frac{3}{y}$, kira-kira sama tidak dengan jawaban kamu?

S1 : "Iya sama hasilnya, jadi bisa pakai dua cara"

2. Penalaran proporsional pada Subjek 2 (S2)

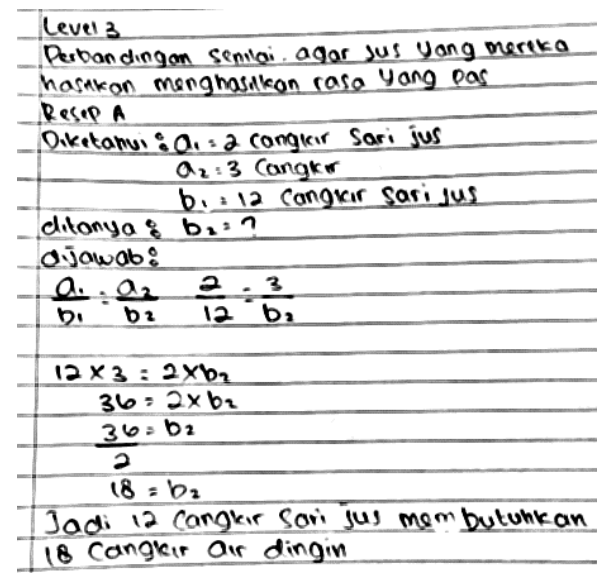

Gambar 2. Hasil Jawaban S2

Gambar 2. merupakan hasil jawaban S2 terhadap soal yang diberikan peneliti. Berdasarkan hasil jawaban S2 pada soal (a), S2 menjawab benar dalam penentuan perbandingan yaitu perbandingan senilai, akan tetapi alasan yang diberikan S2 masih bersifat objektif terkait dengan rasa jus yang dihasilkan tetapi bukan pada membandingkan antara sari jus dengan air dingin (lihat gambar 2).

Pada soal (b), S2 dapat membandingkan dengan tepat kedua rasio yang diketahui pada soal. Terbukti pada jawaban S2 yang menuliskan bahwa resep yang menghasilkan jus paling 
kental adalah resep A, S2 tidak menuliskan alasan terkait jawaban tersebut. Akan tetapi pada hasil wawancara, S2 mampu memberikan alasan yang kurang tepat karena masih melibatkan hubungan selisih pada rasio.

Peneliti : "Untuk soal (b) kamu menjawab resep A, alasannya?”

S2 : "Emm, karena selisihnya”

Peneliti : "Selisih bagaimana maksudnya?”

S2 : "Selisih sari jus dengan air dingin, kalau yang A itu selisihnya 1 kalau yang B itu selisihnya 4. Kalau air dinginnya lebih banyak nantinya encer."

Pada soal (c), S2 menunjukkan pemahamannya terhadap soal yang diberikan dengan menuliskan terlebih dahulu apa yang telah diketahui pada soal, menggunakan permisalan, serta mengkaitkan konsep perbandingan senilai pada penyelesaian soal (lihat Gambar 2.).

3. Penalaran proporsional pada Subjek 3 (S3)

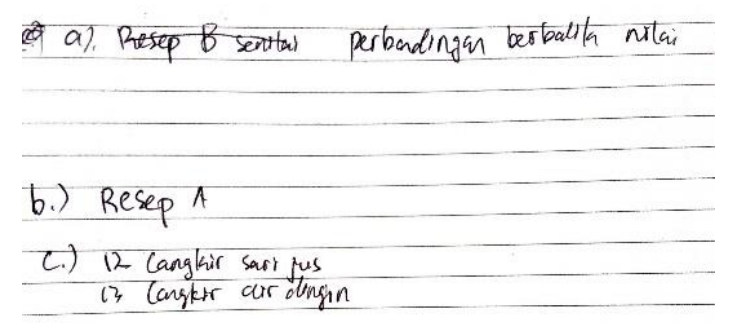

Gambar 3. Hasil Jawaban S3

Gambar 3. merupakan hasil jawaban S3 terhadap soal yang diberikan peneliti. Berdasarkan hasil jawaban S3 pada soal (a), S3 menjawab bahwa resep B senilai, lalu ketika selesai mengerjakan semua soal, S3 melihat kembali soal (a) lalu merubah jawaban disamping dengan jawaban perbandingan berbalik nilai. Akan tetapi S3 tidak menuliskan alasan pada lembar jawaban, melainkan dipertegas melalui hasil wawancara sebagai berikut.

Peneliti : "Mengapa jawaban soal (a) dirubah menjadi perbandingan berbalik nilai? Apakah kamu tidak yakin dengan jawaban sebelumnya?"

S3 : "Iya saya tidak yakin, lalu saya rubah bahwa itu perbandingan berbalik nilai karena resep A dengan resep B beda angkanya, karena itu dinamakan berbalik nilai".

Berdasarkan hasil wawancara tersebut, S3 belum memahami konsep dari perbandingan berbalik nilai, sehingga S3 salah menentukan perbandingan yang digunakan dalam soal tersebut.

Pada soal (b), S3 mampu menjawab dengan tepat bahwa resep yang paling kental adalah resep A, alasan yang diberikan melalui wawancara.

Peneliti : "Mengapa kamu menjawab resep A lebih kental dibanding resep B?"

S3 : "Ya karena selisih dari yang ini (dengan menunjuk resep A) adalah 1 dan selisih resep ini (denganl menunjuk resep B) adalah 4. Jadi lebih kental yang A."

Alasan tersebut menunjukkan bahwa S3 masih terbatas menerapkan konsep selisih dari suatu perbandingan rasio dibandingkan menggunakan konsep perkalian

Pada soal (c), S3 menjawab dengan cepat tanpa perhitungan yang panjang, dengan jawaban 13 cangkir air dingin yang dibutuhkan. 
Peneliti : "Mengapa kamu menjawab 13 cangkir air dingin? Apakah tidak ada perhitungan?"

S3 : "Tidak perlu perhitungan, kan itu berdasarkan pada resep A. Ya langsung saja karena resep A selisihnya 1, jadi soal (c) juga begitu. Yang diketahui 12 sari jus jadi ditambah 1 hasilnya 13 cangkir air dingin".

Berdasarkan alasan S3 tersebut, terlihat S3 melihat pola pada soal yang diketahui untuk menentukan jawaban pada soal. Tetapi tidak menggunakan konsep perbandingan senilai untuk menentukan jawaban yang tepat.

\section{PEMBAHASAN}

Soal yang diberikan kepada subjek terdiri dari tiga tipe masalah penalaran proporsional, yaitu soal (a) yang merupakan soal Membandingkan dan Memprediksi Masalah secara Kualitatif (Qualitative Prediction and Comparison Problems), soal (b) yang merupakan soal Membandingkan Rasio (Numerical Comparison), dan soal (c) yang merupakan soal Mencari nilai yang belum diketahui (missing value problem).

Berdasarkan proses penalaran proporsional pada tiga subjek yang telah diuraikan, selanjutnya dapat ditentukan capaian kategori pada masing-masing subjek.

1. Penalaran proporsional pada Subjek 1 (S1)

Pada soal (a), S1 dapat menentukan dengan tepat bahwa perbandingan tersebut merupakan perbandingan senilai. Hal tersebut dapat dilihat pada gambar 1, dimana S1 memberikan alasan dengan membandingkan banyaknya sari jus buah dan air dingin. Artinya, S1 sudah memahami kuantitas atau nilai yang terlibat pada soal (a) yaitu banyaknya sari jus buah dan banyaknya air dingin. Selanjutnya S1 memberikan alasan bahwa nilai perubahan antar kedua kuantitas adalah sama, yaitu semakin banyak sari buah semakin banyak juga air dinginnya (lihat gambar 1). Sejalan dengan yang diungkapkan oleh Lamon (dalam Raharjanti, Nusantara, \& Mulyanti, 2016) bahwa perbandingan senilai merupakan perbandingan yang perubahan nilai pada satu kuantitas diikuti oleh perubahan kuantitas lain, dengan nilai perubahan yang sama. Selanjutnya ia menyatakan pula bahwa perbandingan berbalik nilai merupakan perbandingan yang perubahan nilai pada satu kuantitas diikuti oleh perubahan kuantitas lain, dengan nilai perubahan yang berlawanan. Oleh karena itu, dalam pemahaman materi perbandingan, tentunya perlu memahami terlebih dahulu kuantitas yang terlibat dan nilai perubahan antar kuantitas agar tidak tertukar antara konsep perbandingan senilai dan berbalik nilai. Jawaban S1 pada soal (a), menunjukkan bahwa S1 sudah memiliki karakteristik sebagai pemikir proposional yaitu pemahaman tentang kovariasi dimana S1 memahami hubungan dua kuantitas yang berbeda.

Pada soal (b), S1 dapat menjawab dengan tepat soal membandingkan rasio. Telah dijelaskan pada hasil penalaran proporsional S1 bahwa alasan berupa deskripsi yang diberikan S1 masih bersifat objektif dan berupa suatu kesimpulan dari dua rasio yang diketahui pada soal. Selanjutnya, S1 memberikan alasan berupa perhitungan dengan mencari rasio yang ekuivalen dengan resep B yaitu membagi bilangan pembilang dengan bilangan penyebut dengan bilangan dua, sehingga didapatkan rasio yang ekuivalen dengan $\frac{4}{8}$ adalah $\frac{2}{4}$. Rasio baru yang didapatkan, selanjutnya dibandingkan dengan dengan rasio pada resep A yaitu $\frac{2}{3}$. S1 mengartikan rasio resep A yaitu $\frac{2}{3}$ dengan menjelaskan bahwa setiap 2 cangkir sari jus menggunakan 3 cangkir air dingin, sedangkan resep B yaitu $\frac{2}{4}$ dengan menjelaskan bahwa setiap 2 cangkir sari jus menggunakan 4 cangkir air dingin, sehingga S1 menyimpulkan bahwa resep A lebih kental dibanding resep B karena setiap 2 cangkir sari jus hanya menggunakan 3 cangkir air dingin. Dari hasil jawaban S1 tersebut, dapat disimpulkan bahwa S1 memahami 
konsep rasio dengan mengkaitkan dengan hubungan dari dua kuantitas yang diketahui. Walle (2007) mengungkapkan bahwa rasio merupakan sebuah bilangan yang menghubungkan dua kuantitas atau ukuran dalam situasi tertentu dalam sebuah hubungan perkalian (berbeda dengan hubungan selisih atau penjumlahan).

Pada soal mencari nilai yang belum diketahui, S1 dapat menuliskan model matematis dari perbandingan senilai. S1 menjawab soal (c) dengan menuliskan proporsi terlebih dahulu, yang merupakan konsep dari perbandingan senilai. Walle (2007) mengungkapkan bahwa proporsi merupakan pernyataan kesetaraan antara dua rasio. Dalam jawaban, S1 membuat rasio dengan menghubungkan dua kuantitas yang berbeda yaitu sari jus dengan air dingin $\frac{2}{3}=$ $\frac{12}{y}$. Model matematis yang dituliskan oleh S1 sama dengan model matematis $\frac{2}{12}=\frac{3}{y}$. Selanjutnya S1 menggunakan perhitungan dengan melibatkan hubungan multiplikatif pada proporsi yang sudah dituliskan dengan benar serta melibatkan strategi kali silang.

Berdasarkan analisis jawaban dan hasil wawancara S1, dapat disimpulkan bahwa S1 dapat menyelesaikan serta memberikan alasan yang tepat pada ketiga tipe masalah yang diberikan yaitu masalah kualitatif untuk menentukan perbandingan senilai atau perbandingan berbalik nilai, masalah membandingakan kedua rasio, dan masalah mencari satu nilai yang belum diketahui. Oleh karena itu, S1 dapat dikategorikan pada kategori 3 karena mampu menyelesaikan ketiga tipe masalah.

2. Penalaran proporsional pada Subjek 2 (S2)

S2 dapat menjawab dengan tepat bahwa pada soal yang diberikan menggunakan konsep perbandingan senilai. Akan tetapi, S2 belum mampu memahami kuantitas yang terlibat pada soal yaitu banyak sari jus dan banyak air dingin, akibatnya S2 salah memberikan alasan yang tepat pada soal (a). Dalam karakteristik pemikir proporsional yang telah dijelaskan diatas, S2 belum memiliki pemahaman tentang kovariasi. Walle (2007) menjelaskan bahwa pemahaman kovariasi terjadi ketika mereka mampu memahami hubungan dimana dua kuantitas bervariasi bersama dan dapat melihat bagaimana variasi dari satu kuantitas sesuai dengan kuantitas yang lain.

Pada soal (b), S2 dapat menjawab dengan tepat dalam membandingkan kedua rasio. S2 memahami hubungan kedua rasio yang diberikan dengan melibatkan hubungan selisih antara sari jus dengan air dingin. Hasil pekerjaan pada soal (c), S2 menuliskan terlebih dahulu apa yang diketahui pada soal, serta yang ditanyakan pada soal. S2 bisa mengenali hubungan antara dua kuantitas yang diketahui, berbeda dengan jawaban pada soal (a). Hal ini sesuai dengan penelitian serupa oleh Khumairoh (2020) yang menjelaskan bahwa pada komponen memahami kovariasi, bahwa siswa mengetahui dengan baik informasi yang diberikan pada soal dan langkah apa yang akan digunakannya. Selanjutnya, S2 menuliskan model matematis dengan tepat sesuai dengan konsep perbandingan senilai dan perhitungan yang tepat dengan menggunakan hubungan multiplikatif melalui strategi kali silang.

Berdasarkan analisis jawaban dan hasil wawancara S2, dapat disimpulkan bahwa S2 dapat menyelesaikan serta memberikan alasan yang tepat pada masalah mencari satu nilai yang belum diketahui. Pada masalah kualitatif dan membandingkan rasio, S2 kurang tepat dalam memberikan alasan yang sesuai dengan konsep perbandingan senilai. Oleh karena itu, S2 dapat dikategorikan pada kategori 1 karena mampu menyelesaikan satu tipe masalah.

3. Penalaran proporsional pada Subjek 3 (S3)

Pada jawaban soal (a), S3 menuliskan bahwa soal yang diberikan peneliti merupakan perbandingan berbalik nilai. Didukung dengan alasan secara lisan melalui wawancara, S3 hanya membandingkan kedua resep berdasarkan perbedaan bilangan pada kuantitas sari jus dan air dingin. Berdasarkan hasil jawaban S3 tersebut, S3 belum memahami kuantitas yang terlibat dalam soal, serta nilai perubahan pada kedua kuantitas yang diketahui, akibatnya S3 salah menafsirkan perbandingan yang tepat. 
Selanjutnya pada soal (b), S3 dengan tepat menjawab resep A yang lebih kental disbanding resep B. Alasan diberikan secara lisan melalui hasil wawancara dengan peneliti, bahwa S3 menggunakan hubungan selisih untuk menentukan resep mana yang lebih kental. Dalam menjawab soal (c), S3 hanya menuliskan 12 cangkir sari jus dan 13 cangkir air dingin (lihat gambar 3). Sama halnya dalam menjawab soal (a), jawaban S3 hanya berdasarkan pada pola bilangan pada resep A yang diketahui pada soal. Karena S3 salah menafsirkan perbandingan yang tepat, maka S3 tidak dapat menyelesaikan perhitungan dengan tepat. Ketidakpahaman S3 terhadap kuantitas yang terlibat pada soal dan nilai perubahan pada kedua kuantitas tersebut yang menyebabkan S3 tidak bisa memodelkan secara matematis apa yang diketahui dan perhitungan dalam penyelesaiannya. Serupa dengan penelitian Raharjanti, Nusantara, \& Mulyanti (2016) yaitu karena siswa kesulitan untuk membedakan permasalahan mana yang termasuk permasalahan yang berkaitan dengan perbandingan senilai atau berbalik nilai pula, siswa melakukan kesalahan dalam membuat pemodelan matematika dari permasalahan tersebut.

Dapat disimpulkan S3 tidak dapat menyelesaikan serta memberikan alasan yang tepat pada ketiga masalah yang telah diberikan. Pada masalah kualitatif, S3 salah menentukan perbandingan yang sesuai dengan soal yang diberikan, serta pada masalah mencari satu nilai yang belum diketahui S3 masih menebak-nebak jawaban yang sesuai dengan pola pada soal. Kemudian pada masalah membandingkan rasio, S3 masih melibatkan hubungan selisih yang berbeda dengan hubungan perkalian. Oleh karena itu, S3 dapat dikategorikan pada kategori 0 karena belum mampu menyelesaikan ketiga tipe masalah dengan tepat.

Capaian kategori di atas dapat dijelaskan dalam bentuk tabel perbedaan capaian kategori kemampuan penalaran proporsional (disajikan dalam Tabel 1.)

Tabel 1. Perbedaan Capaian Kemampuan Penalaran Proporsional

$\begin{array}{ccc}\begin{array}{c}\text { Qualitative Prediction } \\ \text { and Comparison } \\ \text { Problems }\end{array} & \text { Numerical Comparison } & \text { Missing Value } \\ \text { Problem } & \text { Kategori }\end{array}$
Problems

\begin{tabular}{|c|c|c|c|c|}
\hline S1 & $\begin{array}{l}\text { Memiliki pemahaman } \\
\text { tentang kovariasi dimana } \\
\text { S1 memahami hubungan } \\
\text { dua kuantitas berbeda, } \\
\text { sehingga dapat } \\
\text { menentukan jenis } \\
\text { perbandingan yang tepat. }\end{array}$ & $\begin{array}{l}\text { Memahami konsep } \\
\text { rasio dengan } \\
\text { mengkaitkan dengan } \\
\text { hubungan dari dua } \\
\text { kuantitas yang } \\
\text { diketahui, sehingga S1 } \\
\text { dapat memberikan } \\
\text { alasan perhitungan } \\
\text { yang tepat dalam } \\
\text { menentukan } \\
\text { kekentalan suatu resep. }\end{array}$ & $\begin{array}{l}\text { Dapat menuliskan } \\
\text { model matematis dari } \\
\text { perbandingan senilai, } \\
\text { serta melibatkan } \\
\text { hubungan perkalian } \\
\text { dan strategi kali silang } \\
\text { dalam penyelesaian } \\
\text { soal. }\end{array}$ & Kategori 3 \\
\hline & $\begin{array}{lr}\text { Qualitative } & \text { Prediction } \\
\text { and } & \text { Comparison } \\
\text { Problems } & \end{array}$ & Numerical Comparison & Missing Value Problem & Kategori \\
\hline $\mathrm{S} 2$ & $\begin{array}{l}\text { Menjawab dengan tepat } \\
\text { jenis perbandingan yang } \\
\text { sesuai, tetapi belum } \\
\text { memiliki pemahaman } \\
\text { mengenai kovariasi } \\
\text { karena alasan yang } \\
\text { diberikan masih bersifat } \\
\text { objektif }\end{array}$ & $\begin{array}{l}\text { Menjawab dengan tepat } \\
\text { masalah } \\
\text { membandingkan rasio, } \\
\text { tetapi alasan yang } \\
\text { diberikan kurang tepat } \\
\text { karenaryasih } \\
\text { melibatkan hubungan } \\
\text { selisih dalam }\end{array}$ & $\begin{array}{lr}\text { Dapat menuliskan apa } \\
\text { yang } & \text { diketahui, } \\
\text { ditanyakan, } & \text { dan } \\
\text { menuliskan } & \text { model } \\
\text { matematis } & \text { dari } \\
\text { perbandingan } & \text { senilai, } \\
\text { dan menggunakan } \\
\text { hubungan perkalian }\end{array}$ & ri 1 \\
\hline
\end{tabular}




\begin{tabular}{|c|c|c|c|}
\hline & & $\begin{array}{l}\text { membandingkan kedua } \\
\text { rasio }\end{array}$ & $\begin{array}{lll}\text { dengan } & \text { strategi } & \text { kali } \\
\text { silang } & & \end{array}$ \\
\hline S3 & $\begin{array}{l}\text { Tidak dapat menentukan } \\
\text { jenis perbandingan yang } \\
\text { tepat karena belum } \\
\text { memahami kuantitas } \\
\text { yang terlibat pada soal }\end{array}$ & $\begin{array}{l}\text { Menjawab dengan tepat } \\
\text { masalah } \\
\text { membandingkan rasio, } \\
\text { tetapi alasan yang } \\
\text { diberikan kurang tepat } \\
\text { karenar masih } \\
\text { melibatkan hubungan } \\
\text { selisih dalam } \\
\text { membandingkan kedua } \\
\text { rasio }\end{array}$ & $\begin{array}{l}\text { Tidak dapat } \\
\text { menentukan kuantitas } \\
\text { yang tepat karena S3 } \\
\text { salah menafsirkan } \\
\text { perbandingan yang } \\
\text { tepat sehingga cara } \\
\text { penyelesaian yang } \\
\text { digunakan adalah cara } \\
\text { menebak kuantitas } \\
\text { yang sesuai pada soal }\end{array}$ \\
\hline
\end{tabular}

Sumber: diolah dari data penelitian

\section{SIMPULAN}

Berdasarkan hasil penelitian, dapat disimpulkan bahwa perkembangan kemampuan penalaran proporsional yang dikuasai siswa berbeda-beda yaitu subjek 1 mencapai kategori 3, subjek 2 mencapai kategori 1 dan subjek 3 mencapai kategori 0. Pada subjek 1 (S1) dikategorikan pada kategori 3, artinya terdapat tiga kemampuan penyelesaian masalah penalaran proporsional yang dikuasai yaitu dapat menyelesaikan serta memberikan alasan yang tepat pada ketiga tipe masalah yang diberikan yaitu masalah kualitatif untuk menentukan perbandingan senilai atau perbandingan berbalik nilai, masalah membandingakan kedua rasio, dan masalah mencari satu nilai yang belum diketahui. Sedangkan pada subjek 2 (S2) dikategorikan pada kategori 1, artinya terdapat satu kemampuan penyelesaian masalah penalaran proporsional yang dikuasai yaitu dapat menyelesaikan serta memberikan alasan yang tepat pada masalah mencari satu nilai yang belum diketahui. Pada masalah kualitatif dan membandingkan rasio, S2 kurang tepat dalam memberikan alasan yang sesuai dengan konsep perbandingan senilai. Dan untuk subjek 3 (S3) dikategorikan pada kategori 0, artinya tidak memiliki kemampuan penyelesaian masalah penalaran proporsional yang dikuasai. Pada masalah kualitatif, S3 salah menentukan perbandingan yang sesuai dengan soal yang diberikan, serta pada masalah mencari satu nilai yang belum diketahui S3 masih menebak-nebak jawaban yang sesuai dengan pola pada soal. Kemudian pada masalah membandingkan rasio, S3 masih melibatkan hubungan selisih yang berbeda dengan hubungan perkalian. Sehingga dapat disimpulkan bahwa S3 tidak dapat menyelesaikan serta memberikan alasan yang tepat pada ketiga masalah yang telah diberikan.

\section{DAFTAR RUJUKAN}

Fuat. (2020). Geometri Datar: Individual Textbook. Pasuruan: Lembaga Academic \& Research Institute.

Fuat, F., Susanto, K., \& Aini, F. Q. (2020). Classificational and Theoretical Execution Misconceptions' Classification of Misconceptions Based on Students Concepts in Plane Geometry. Journal of Education and Learning Mathematics Research (JelmaR), 1(2), 8-21. https://doi.org/10.37303/jelmar.v1i2.20

Fuat, F., Nusantara, T., Hidayanto, E., \& Irawati, S. (2020). The Exploration of Argument Scheme Expression in Students' Proof Construction. International Journal of Scientific \& Technology Research (IJSTR), 9(1), 2369-2372. Retrieved from: The-Exploration-OfArgument-Scheme-Expression-In-Students-Proof-Construction.pdf (ijstr.org) 
Irawati, T. N. (2015). Mengembangkan Kemampuan Guru Matematika dalam Membuat Soal Penalaran Proporsional Siswa SMP. Seminar Nasional Matematika dan Pendidikan Matematika, 1101-1106.

Khumairoh B., Amin S. M., dan Wijayanti P. (2020). Penalaran Proporsional Siswa Kelas Menengah dalam Menyelesaikan Masalah Matematika Ditinjau dari Adversity Quotient. PEDAGOGIA: Jurnal Pendidikan, 9(1), 67-80. https://doi.org/10.21070/pedagogia.v9i1.259

Ojose, B. (2015). Common Misconceptions in Mathematics. United States of America: University Press of America.

Raharjanti, M., Nusantara, T., \& Mulyati, S. (2016). Kesalahan Siswa dalam Menyelesaikan Permasalahan Perbandingan Senilai dan Berbalik Nilai. Prosiding Konferensi Nasional Penelitian Matematika dan Pembelajarannya (KNPMP I), 312-319. Retrieved from: https://www.researchgate.net/publication/303215282.

Uyun, S. N., \& Fuat, F. (2020). Kemampuan Disposisi Berpikir Kritis Siswa yang Berkategori Rendah dalam Memecahkan Masalah Persamaan Nilai Mutlak Linier Satu Variabel. Jurnal Pendidikan Matematika (JPM), 6(2), 58-69. http://dx.doi.org/10.33474/jpm.v6i2.5370

Walle, J.A. (2007). Pengembangan Pengajaran Matematika Sekolah Dasar dan MeMenengah. Edisi ke-6 jilid 2. Jakarta: Erlangga. 
190 Fuat \& Wulan

JKPM (Jurnal Kajian Pendidikan Matematika) Vol.6, No. 2 (2021) 